\title{
International Investment Law and the Regulation of the Seabed
}

\author{
James Harrison
}

$1 \quad$ Introduction*

Modern technology has increased the possibilities for greater parts of the oceans and ocean floor to be opened up for exploitation. Oil and gas extraction is still one of the most prevalent seabed activities, with almost a third of oil consumed in the world coming from seabed drilling ${ }^{1}$ and new fields continue to be discovered in ever deeper waters. Innovations in marine technology also mean that many other uses of the seabed are now anticipated. One of the fastest growing offshore activities is renewable energy generation, which involves the attachment of structures, platforms or devices to the seabed in order to capture energy from wind, wave, or tidal power. ${ }^{2}$ Many companies are also turning to the deep seabed as a source of valuable minerals, such as manganese, cobalt, copper and others. Significant deposits of these metals are thought to be located on many parts of the ocean floor, both within and beyond national jurisdiction. ${ }^{3}$ These examples illustrate the diversity and fastgrowing volume of the types of 'seabed investments' that will be addressed in this chapter.

Many of the seabed activities with which we are concerned in this chapter are undertaken by private actors, operating under a licence or concession from the coastal state. Coastal states have a significant degree of control over what seabed activities may take place in the waters adjacent to their territory. The

* The author would like to thank participants in the workshop held in Oslo for their feedback, as well as Filippo Fontanelli for his comments on a previous draft of this chapter.

1 J. Rochette, Towards an International Regulation of Offshore Oil Exploitation, IDDRI Working Paper No. 15, July 2012, 5. See also Global Oceans Commission, From Decline to Recovery - A Rescue Package for the Global Ocean, Summary Report 2014, 35.

2 For an overview of the relevant technology, see D. Leary and M. Esteban, 'Climate Change and Renewable Energy from the Ocean and Tides' (2009) 24 I.J.M.C.L. 617-651. The world's first full-scale floating windfarm was announced off the coast of Scotland in 2017 and new projects are emerging. See ввс, 'World's first floating wind farm emerges off coast of Scotland,' 23 July 2017 <http://www.bbc.co.uk/news/business-40699979>.

3 See P.A. Rona, 'The Changing Vision of Marine Minerals' (2008) 33 Ore Geology Rev. 618. 
1982 United Nations Convention on the Law of the Sea (UNCLOS) confers 'sovereign rights' on the coastal state over almost all seabed activities taking place in waters up to 200 nautical miles from their coast, ${ }^{4}$ as well as on the seabed up to the edge of the continental margin. ${ }^{5}$ The rights of the coastal state are inherent and they do not depend upon proclamation or occupation. ${ }^{6}$ They are also exclusive, so that if the coastal state does not explore the continental shelf or exploit its natural resources, no one may undertake these activities without the express consent of the coastal state. ${ }^{7}$ Operators will therefore have to comply with the laws and regulations established by the coastal state in relation to the exploitation of the seabed.

Most states will want to encourage broad participation in offshore activities, whilst also ensuring that companies exploiting seabed resources respect the marine environment and make some contribution to the national economy, through taxes, royalties, or other benefit-sharing arrangements. At the same time, the discretion of the coastal state to design its domestic legal framework will also be constrained by international law. Many states have entered into treaties, which seek to protect the interests of foreign investors, by imposing minimum standards of treatment. These instruments also allow companies to bring claims directly against states, without having to rely upon diplomatic protection from their own state. This is a burgeoning field of international law, with an increasing number of disputes being initiated. ${ }^{8}$ There have been only a handful of disputes concerning seabed activities to date, but it is worth noting that land-based energy and mineral extraction projects are currently the biggest users of investor-state arbitration. ${ }^{9}$

This chapter explores the extent to which the investment treaty framework can be applied to seabed investments and, if so, the scope of protection that may be expected by investors. It focuses on seabed investments made within the jurisdiction of coastal states. The chapter is divided into three parts. Firstly, there will be a brief introduction to the international investment treaty regime

4 This includes sovereign rights for the purpose of exploring and exploiting the natural resources of the seabed, as well as jurisdiction over the placement of installations and structures for the production of energy from the water, currents and winds; see 1982 United Nations Convention on the Law of the Sea (UnCLOS), Articles 56-57, 60.

5 UNCLOS, Articles $76-77$.

6 UnClos, Article 77(3).

7 UnClos, Article 77(2).

82017 saw at least 65 investment claims being initiated, bringing the total number of known claims to 855; see UNCTAD, World Investment Report 2018, 91.

9 The International Centre for the Settlement of Investment Disputes (ICSID) reports that oil gas and mining projects are the subject of $26 \%$ of claims, whilst electric power \& other energy are the subject of $17 \%$ of claims; The ICSID Caseload - Statistics, Issue 2016-1, 12. 
as it has evolved since its inception in the late 1950s. Secondly, the chapter addresses the geographical scope of international investment treaties, considering the extent to which they can be applied to offshore investments. This seemingly simple question has received very little attention in the literature to date and the discussion in this part will reveal a number of complexities that arise both from the ambiguous nature of the relevant treaty provisions, and also from the various scenarios in which seabed investments can take place. Thirdly, the chapter considers the substantive protections that are available if a seabed investment is found to fall within the scope of an investment treaty. This is an issue that raises complex questions about the balance between the rights of states to regulate activity falling under their jurisdiction and the limits that are imposed on those rights for the benefit of economic actors. The analysis demands an understanding of how international investment law interacts with relevant rules in the international law of the sea or international environmental law. Given the intensification in seabed activity around the world, this analysis will provide an important contribution to clarifying key issues that arise in the interpretation and application of investment standards in this context. Ultimately, the chapter aims to propose a framework of principles to reconcile these two areas of law.

\section{2 The International Investment Law Framework}

International investment law can trace its origins to the rules of customary international law relating to the protection of aliens, but international investment law emerged in its current form at the end of the 1950s, when states started to negotiate treaties for the protection of their nationals investing overseas. ${ }^{10}$ These treaties aimed to both encourage the expansion of foreign investment between the parties and to create 'favourable conditions for nationals and companies of either State in the territory of the other State."11 This objective was achieved through the elaboration of substantive standards of protection. Another important feature of most investment treaties is that they confer a direct right on investors to bring a claim against a host state through arbitral proceedings. Indeed, it has been suggested that 'the availability of arbitration

10 The first modern Bilateral Investment Treaty (вІт) was concluded between Germany and Pakistan on 25 November 1959.

11 Germany-Pakistan BIT, preamble. Similar language is used in the preamble of many other BITs. 
is probably the most important part of the "treatment" the foreign investor is looking for.'12

Over time, the number of investment treaties has increased incrementally to the point where there are 3,322 agreements in existence today. ${ }^{13}$ Coverage of investment treaties is still far from universal, although most states in the world are party to at least one investment agreement. ${ }^{14}$ Most of these treaties are bilateral in nature, ${ }^{15}$ although there is a recent trend towards the conclusion of so-called mega-regional economic agreements that bring together larger groupings of states within a region into a closer economic relationship. Examples include the Convention on Protection of the Rights of the Investor, ${ }^{16}$ the North American Free Trade Agreement (NAFTA), ${ }^{17}$ the China/Korea/Japan Trilateral Investment Agreement, ${ }^{18}$ and the Trans-Pacific Partnership (TPP). ${ }^{19}$

Another important agreement in the current context is the Energy Charter Treaty (ЕСТ) ${ }^{20}$ which contains a chapter dedicated to investment protection in the energy sector. ${ }^{21}$ Its scope includes all 'economic activity concerning the exploration, extraction, refining, production, storage, land transport, transmission, distribution, trade, marketing or sale of energy materials or products. ${ }^{22}$ This includes prospecting and exploration for oil and gas, as well as construction and operation of power generation facilities, including those powered

12 Impregillo v Argentina, ICSID Case No. ARB/07/17, Award, 21 June 2011, Dissenting Opinion of Bridgette Stern, para. 32.

13 UNCTAD (n8) 88. The Report notes that the total fell for the first time in 2017, due to several IIAs being terminated, but that an increasing number of IIAs take the form of regional agreements which create many treaty relationships between the contracting parties. The text of most BITs and other investment agreements cited in this paper can be found on the UNCTAD website: <http://investmentpolicyhub.unctad.org/IIA > .

14 See <http://investmentpolicyhub.unctad.org/IIA $>$.

15 At the last count, there were 2946 BITs; UnCTAD (n8) 101.

161997 Convention on Protection of the Rights of the Investor, concluded by Armenia, Belarus, Moldova, Tajikistan, Kazakhstan, Kyrgyzstan, and Russia. Russia withdrew from the Convention in 2007.

17 The nafta was concluded in 1992 between the United States, Canada and Mexico. It entered into force in 1994. At the time of writing, major reforms of NAFTA were expected to be finalized in the near future, which would include renaming the instrument as the United States, Mexico and Canada Agreement.

18 The Trilateral Investment Agreement was concluded in 2012 and entered into force in 2014.

19 The трP was negotiated between the United States, Australia, Brunei, Canada, Chile, Malaysia, Mexico, New Zealand, Peru, Singapore, Vietnam and Japan. The US pulled out of the TPP in January 2017.

20 The ECT was concluded in 1994. It entered into force on 1998. It has $5^{2}$ parties.

21 ECT, Articles 10-17.

22 ECT, Article 1(5). 
by wind and other renewable resources. ${ }^{23}$ This instrument is also important because it has become the most frequently invoked investment agreement in terms of investor-state arbitration. ${ }^{24}$

What is important to remember is that all of these instruments have been individually negotiated and therefore no two treaties are identical. With that in mind, the following analysis will attempt to identify major trends in investment treaty drafting and interpretation in order to discover the extent to which investment treaties can be applied to seabed activities and what types of protection may be afforded to seabed investments. At the same time, it must be borne in mind that individual treaties may differ in their precise terms, which may influence the outcome in a particular dispute.

\section{The Application of Investment Treaties to Seabed Activities}

\subsection{The Application of Investment Treaties to Maritime Zones}

To identify the geographical scope of investment treaties, we must look firstly to the terms of the treaties themselves. ${ }^{25}$ Most early investment treaties simply apply to investments 'in [the] territory' 26 or 'situated in the territory of' a contracting party. ${ }^{27}$ For example, such language is found in the first investment treaty concluded between the United Kingdom and Egypt, which refers to the protection of investments within the territory of the two countries, without any explanation of what is meant by territory. ${ }^{28}$ The first French B ITs evidence a similar level of ambiguity, simply referring to 'investissements ... situé sur le territoire de l'autre Etat ...229 Even the 1992 NAFTA, seen by many as a watershed for a new style of investment agreement, ${ }^{30}$ simply provides that the investment protection chapter applies to 'investments of investors of

23 See Understanding with respect to Article I(5) of the ECT.

24 UNCTAD (n8) 93, which attributes 113 cases as being initiated under the ЕCT.

25 Note that there may be other provisions which define the scope of the treaty, potentially excluding some seabed investments from protection; see e.g. the discussion of sectoral exclusions in S. Trevisanut and N. Giannopoulos, 'Investment Protection in Offshore Energy Production: Bright Sides of Regime Interaction' (2018) 19Journal of World Investment and Trade 789, 794-795.

26 E.g. 1991 Austria - Korea BIт, Article 3(2); 1959 Germany-Pakistan BIт, Article 3.

27 E.g. 1970 Belgium - Indonesia BIт, Article 5.

$28 \quad 1975$ UK-Egypt BIт.

29 See e.g. 1975 France-Congo BIt, Article 2.

$30 \quad$ N.W. Ranieri, 'NAFTA: An Overview', in L. Trakman and N.W. Ranieri (eds), Regionalism in International Investment Law (OUP, 2013) 90. 
another Party in the territory of the Party. ${ }^{31}$ Such ambiguities are still found today. The TPP is a case in point, as it simply defines a covered investment as 'an investment in its territory' without defining territory. ${ }^{32}$

The language of these treaties creates some ambiguity about their precise geographical scope. Their application to seabed activities will depend upon the interpretation of the phrase 'territory.' This is in fact a question that has received little attention in either the jurisprudence or the literature. Whilst it clearly applies to investments made within the land territory of a state, does it also extend to the maritime zones of a coastal state? If so, does it include both the 'territorial sea' over which the coastal state exercises sovereignty ${ }^{33}$ and other maritime zones in which the coastal state has sovereign rights for the purpose of exploring and exploiting natural resources? ${ }^{34}$

The inclusion of territorial sea within the scope of territory is a relatively unproblematic proposition. It is a general principle of treaty law that the application of treaties extends to 'the entire territory of each party'35 and when drafting the rules on this subject, the International Law Commission noted that the reference to the 'entire territory' is 'a comprehensive term designed to embrace all the land and appurtenant territorial waters and air space that constitute the territory of the State. ${ }^{36}$ This phrase is understood as the internal waters and territorial sea of a state. ${ }^{37}$ At the same time, the Commission did not explicitly mention the continental shelf as being part of the territory of a state, despite the fact that the Commission had shortly beforehand been involved in codifying rules on coastal state jurisdiction over the seabed. ${ }^{38}$ Not too much significance should be attributed to this omission, however, as the question does not appear to have been considered in detail by the Commission. ${ }^{39}$

Indeed, there are other reasons to believe that the term 'territory' should be interpreted to extend to seabed activities on the continental shelf. It must be remembered that the very notion of the continental shelf is premised upon

$31 \quad$ NAFTA, Article 1101(1)(b).

32 TPP, Article 9.1.

33 UNCLOS, Article 2.

34 UNCLOS, Articles 56 and 77.

351969 Vienna Convention on the Law of Treaties, Article 29.

36 International Law Commission, 'Commentary to Article 25 of the Draft Articles on the Law of Treaties' (1966 - II) Yearbook of the International Law Commission 213.

37 See O. Doerr and K. Schmalenbach, Vienna Convention on the Law of Treaties: A Commentary (Springer, 2012) 497.

38 The Commission initiated discussion on the continental shelf in 1950 and it produced draft articles, which were used as the basis for the subsequent $195^{8}$ Convention on the Continental Shelf.

Doerr and Schmalenbach (n37) 496. 
the natural prolongation of a coastal state's land territory into the seabed. In the words of the International Court of Justice (ICJ) in one of its seminal judgments on the continental shelf, 'the submarine areas concerned may be deemed to be actually part of the territory over which the coastal State already has dominion - in the sense that, although covered with water, they are a prolongation or continuation of the territory, an extension of it under the sea. ${ }^{30}$ Whilst the Court was speaking in general terms and it was not concerned with providing a legal interpretation of the term 'territory', its dicta in this respect nevertheless would support a broad understanding of the concept of territory for the purpose of international investment law. ${ }^{41}$

A teleological interpretation may also support a broad understanding of 'territory' for the purposes of international investment law. ${ }^{42}$ One of the principal objectives of investment treaties is the protection of investment and it has thus been argued that an interpretation that offers more protection to investors should be preferred in cases of doubt. ${ }^{43}$ From this perspective, an interpretation of a treaty that excludes investments that undoubtedly fall within a coastal state's jurisdiction as a matter of general international law could be considered as an unreasonable result that undermines the objectives of the treaty. There are obviously limits to this approach and the object and purpose cannot be used as a factor to override other more compelling arguments that suggest a different interpretation, for example an explicit exclusion of continental shelf investments by the contracting parties. ${ }^{44}$ Nevertheless, it would support an assumption in favour of extending protection to seabed investments under the jurisdiction of the coastal state.

$40 \quad$ North Sea Continental Shelf Cases (1969) ICJ Reports 3, para. 43.

41 See also the Aegean Sea Continental Shelf Case, although the question in this case was not whether the continental shelf was a form of territorial right, but rather whether the dispute relating to the continental shelf boundary between Greece and Turkey was one which 'relates to the territorial status' of Greece; Aegean Sea Continental Shelf Case (1977) ICJ Reports 3, para. 81.

42 A similar argument has been made in the context of extending the protection of investment treaties to occupied territories; see R. Happ and S. Wuschka, 'Horror Vacui: Or why investment treaties should apply to illegally annexed territories' (2016) 33Journal of International Arbitration 245, 261.

$43 S G S v$ Philippines, ICSID Case No. ARB/02/6, Decision on Jurisdiction, 29 January 2004, para. 116; Sanum v Laos, PCA Case No. 2013-13, Award of Jurisdiction, 13 December 2013, para. 240.

44 Indeed, as Happ and Wuschka point out, the award in Sanum $v$ Laos was ultimately annulled because it was contradicted by diplomatic exchanges by the parties to the treaty; Happ and Wuschka (n42) 261. 
In practice, it would appear that this issue is not controversial. Mobil and Murphy Oilv Canada involved a claim by two oil companies in relation to their investments on the continental shelf of Canada. ${ }^{45}$ In this case, the geographical scope of the NAFTA was not even raised by the parties and it appears to have been assumed by the tribunal that the concept of 'territory' in the agreement extended to this type of investment.

More recent developments in treaty drafting also confirm a broader geographical application of international investment law to maritime zones beyond the territorial sea. Practice on this issue appears to have taken a turn in the mid-199os, when we see the question of the application of investment treaties to maritime zones being addressed in more explicit terms. For example, the Portugal-Korea BIT, concluded in May 1995, explicitly defines the term territory as 'the territory of either of the Contracting Parties, as defined by their respective laws, including the territorial sea, and any other zone over which the Contracting Party concerned exercises, in accordance with international law, sovereignty, sovereign rights or jurisdiction. ${ }^{46}$ This is also the practice that has been adopted by the European Union (EU) in its negotiation of investment provisions in its recent Free Trade Agreements ${ }^{47}$ and it is a practice that is adopted in many modern model BITs. ${ }^{48}$ This widespread practice supports the inclusion of maritime zones within the concept of 'territory' for the purposes of international investment law. ${ }^{49}$

Finally, it is worthwhile noting that investment treaties generally cannot be interpreted to apply to seabed investments in areas beyond national jurisdiction. Such areas are clearly not within the territory or maritime zones of a coastal state ${ }^{50}$ and therefore investors in these areas would have to rely upon the sui generis provisions of Part XI of UNCLOS if they were to seek protection of their investments. ${ }^{51}$

45 Mobil and Murphy Oil $v$ Canada, ICsid Case No. ARB(AF)/07/4, Decision on Liability and Principles of Quantum, 22 May 2012.

46 Portugal-Korea BIT, Article 1(4). See also Paraguay-Switzerland BIT, Article 1(4).

47 EU - Viet Nam Free Trade Agreement, Article 801.

48 UK Model вIт, Article 1(e); Italy Model вгт, Article I(6); India Model вiт, Article 1(f); Canada Model BIT, Article 1; Germany Model BIт, Article 1(4); US Model BIT, Article 1.

49 Not all treaties necessarily include maritime zones within the concept of 'territory.' Some treaties explicitly distinguish territory and maritime areas, but nevertheless include the latter within their scope of application. See e.g. 2007 France-Seychelles BIT, Article 1(4); ECT, Article 10(1).

50 UNCLOS, Article 137(1).

$5^{1}$ See particularly Unclos, Article 152(1), Annex III, Articles 17-19. See also Part XI Agreement, Annex, Section 1, para. 13. 


\subsection{The Application of Investment Treaties to Joint Exploitation Zones and Disputed Maritime Areas}

The previous discussion was based on the assumption that an investment was made within the established maritime boundaries of a coastal state. Yet, in some parts of the ocean, states have been unable to agree upon maritime boundaries. Two scenarios may present themselves in this context.

\subsubsection{Application to Joint Exploitation Zones}

In the first scenario, coastal states may have chosen to pursue joint development of seabed resources in an area in which they cannot agree on the appropriate maritime boundary. Such arrangements are explicitly encouraged by UNCLOS. ${ }^{52}$ There are various types of arrangement that have been entered into for this purpose..$^{53}$ One common mechanism is the establishment of joint commission, which is granted powers to authorize and regulate seabed activities within a joint development area. An example is provided by the Thailand-Malaysia Memorandum of Understanding, which identifies an area of overlapping claims and establishes a Joint Authority composed of representatives of both countries. ${ }^{54}$ This body has legal personality ${ }^{55}$ and it assumes 'all rights and responsibilities on behalf of both parties for the exploration and exploitation of the non-living natural resources of the seabed and subsoil in the overlapping area ... and also for the development, control and administration of [said] area. ${ }^{56}$ The Joint Authority is empowered to enter into contracts with oil and gas companies wishing to carry out operations in the

52 UnClOs, Articles 74(3) and 83(3). See also chapter 8 of this book, E. Røsæg, 'Framework legislation for commercial activities in the Area'; J. Dingwall, 'International Investment Protection in Deep Seabed Mining Beyond National Jurisdiction' (2018) 19 Journal of World Investment and Trade 890-929.

53 For a useful overview of arrangements, see M. Miyoshi, 'The Joint Development of Offshore Oil and Gas in Relation to Maritime Boundary Delimitation', Maritime Briefing, Volume 2, Number 5, 1999. See also P. Tzeng, 'Investment Protection in Disputed Maritime Areas' (2018) 19 Journal of World Trade and Investment $828,855-858$.

541979 Memorandum of Understanding between Malaysia and Thailand on the Establishment of the Joint Authority for the Exploitation of the Resources of the Seabed in a Defined Area of the Continental Shelf of the Two Countries in the Gulf of Thailand (1979 MOU). For another example, see the 2001 Treaty between the Federal Republic of Nigeria and the Democratic Republic of São Tomé e Príncipe on the Joint Development of Petroleum and other Resources.

551990 Agreement between the Government of Malaysia and the Government of Thailand on the Constitution and other Matters relating to the Establishment of the Malaysia-Thailand Joint Authority (1990 Agreement), Article 1. 1979 MOU, Article III (2). 
Joint Development Area. ${ }^{57}$ It is also the Joint Authority that is responsible for formulating policies for seabed activities in the Joint Development Area. ${ }^{58}$

For present purposes, the question is how such arrangements would be addressed from the perspective of international investment law. Would such a Joint Development Area be classified as being within 'the territory' of a coastal state for the purposes of international investment law? This is a difficult question given that the whole purpose of such arrangements is to avoid the determination of which state has sovereignty or sovereign rights over a contested area. Thus, it may be better to consider a Joint Development Area as a tertium genus. ${ }^{59}$

Another problem that arises for investors in such a scenario is that the arrangement may confer the power to regulate seabed activities on an autonomous international organization with distinct legal personality. If so, any regulatory measures adopted by the organization arguably could not be attributed to the state that is party to the investment treaty. ${ }^{60}$ Instead, it raises issues of the responsibility of the organization itself. ${ }^{61}$ It follows that the investor will not be able to claim protection under the treaty and its remedies will be limited to those that are available on the basis of its contractual relationship with the organization. Thus, it is important that the investor ensures that a contract contains relevant provisions to safeguard its interests against interference from the organization, such as the inclusion of minimum standards of treatment or a stabilization clause, ${ }^{62}$ as well as an appropriate dispute settlement mechanism. ${ }^{63}$

\subsubsection{Application to Disputed Maritime Areas}

In the second scenario, states may not be able to reach agreement on provisional arrangements to apply to a disputed area, but they will both continue

$57 \quad 1990$ Agreement, Article 7(2)(e).

$58 \quad 1990$ Agreement, Article 7(1).

59 For other uses of this concept in the law of the sea, see Fisheries Jurisdiction Case (1974) ICJ Reports 3, para. 54 .

6o See discussion in the International Law Commission, 'Commentary to Chapter IV of the Draft Articles on State Responsibility' (2001 - II) Yearbook of the International Law Commission 64 .

61 By way of example, albeit in the context of international human rights law, see Behrami and Behramiv France, Judgment of the European Court of Human Rights, 2 May 2007.

62 See e.g. L Cotula, 'Regulatory Takings, Stabilization Clauses and Sustainable Development', paper presented at the OECD Global Forum on International Investment, 27-28 March 2008. Available at: http://www.oecd.org/investment/globalforum/40311122 .pdf.

63 For discussion of contractual claims in this context, see Tzeng $\left(n_{53}\right) 85^{0}-85^{2}$. 
to claim authority therein. There are many maritime boundaries around the world that remain un-delimited ${ }^{64}$ and several areas in which more than one coastal state claims rights.

It is generally accepted that international law does not prevent states from carrying out unilateral prospecting of seabed resources in a disputed area, although they may be obliged to refrain from activities that might affect the rights of other states. ${ }^{65}$ The fact that investments may be made in disputed areas is demonstrated by the maritime boundary case between Cote d'Ivoire and Ghana, in which Cote d'Ivoire alleged that Ghana had proceeded to authorize seabed activities in an area that Cote d'Ivoire argued belongs to it. ${ }^{66}$

The question that arises for present purposes is if the investor would have a claim against the state that had authorized it to proceed, if the investor is later forced to stop its activity because the area is found to be under the sovereignty of another state. ${ }^{67}$ Strictly speaking, in this situation, the investment is not within the maritime zone of the authorizing state and therefore an investment treaty would not prima facie be applicable. Yet, it seems unfair to allow a state to evade responsibility when it had itself led an investor to believe that it did have jurisdiction over the disputed area. This situation may thus call for the application of the principle of ex factis jus oritur, so that the exercise of de facto sovereign rights in a contested area could be sufficient to establish that an investment was in the maritime zone of the state. ${ }^{68}$ An alternative approach

64 See C. Schofield and C. Carleton, 'Key Technical Issues in the Law of the Sea Dispute Resolution and the Role of the Technical Expert', in A.G. Oude Elferink and D. Rothwell (eds), Oceans Management in the 21st Century: Institutional Frameworks and Responses (Martinus Nijhoff, 2004) 254.

65 See Miyoshi (n53) 4. See also Aegean Sea Continental Shelf Case (Provisional Measures) (1976) ICJ Reports 3, paras 28-33; BIICL, Report on the Obligations of States under Articles 74(3) and 83(3) of UNCLOS in respect of Undelimited Maritime Areas (2016).

66 Ghana raised the impacts on investors in its pleadings concerning the imposition of provisional measures pending the settlement of the dispute; see Dispute concerning Delimitation of the Maritime Boundary between Ghana and Cote d'Ivoire in the Atlantic Ocean, ITlos Case No. 23, Provisional Measures Order, 25 April 2015, para. 85. Ultimately, the Special Chamber ordered Ghana to 'take all the necessary steps to ensure that no new drilling either by Ghana or under its control takes place in the disputed area' (para. 102), although the order did not apply to 'ongoing activities ... in respect of which drilling has already taken place.' (para. 99) A final judgment was delivered by the Special Chamber on 23 September 2017 in which it absolved Ghana from any responsibility for carrying out unlawful activities in the disputed area.

67 A more complicated set of legal questions arise if an investment claim is made whilst a sovereignty dispute is ongoing; see Tzeng ( $\left.n_{53}\right)$ 839-848.

68 Similar arguments have been made in relation to unlawfully annexed territories; Happ \& Wuschka (n42) 264 . 
would be to apply the doctrine of estoppel to prevent a state from pleading a lack of jurisdiction in circumstances in which it had previously asserted its jurisdiction to the detriment of the investor. ${ }^{69}$ Whichever approach is preferred, the result is to extend the application of investment treaties to disputed maritime zones.

\section{$4 \quad$ Standards of Investment Protection under Investment Treaties and Implications for the Regulation of Seabed Investments}

\subsection{Investment Protection Standards}

Having considered the geographical scope of investment treaties, it is now necessary to examine what type of protection may be granted to an investment thereunder. In the following section, particular attention is given to the manner in which investment agreements may constrain coastal states in exercising their regulatory powers in relation to seabed activities.

\subsubsection{Pre-investment Protection}

Generally speaking, states have a broad degree of discretion as to which investments they allow to take place within their territory and most investment treaties leave this discretion unfettered, as protection only kicks in once the investment has been made. However, a number of more modern investment treaties do impose some obligations on states at this initial decision-making stage. In particular, it is increasingly common to find a requirement that states grant most-favoured nation treatment and national treatment to investors with respect to the establishment, acquisition or expansion of their investments. ${ }^{70}$ Such requirements would not restrict the content of any decision, but they would demand that decisions are made in a non-discriminatory manner.

69 For a discussion of estoppel in international law, see I.C. MacGibbon, 'Estoppel in International Law' (1958) 7 I.C.L.Q. 468-513; C. Brown, 'A Comparative and Critical Assessment of Estoppel in International Law' (1996) U. Miami L. Rev. 369 . However, see Tzeng $\left(n_{53}\right) 847$ who argues that this approach 'is arguably at odds with the tribunal's arguably inherent duty to examine proprio motu its own jurisdiction.'

70 See e.g. TPP, Articles 9.4 and 9.5 applying MFN treatment and National Treatment to the establishment of investments. ECT, Article 10(1) requires states to 'create stable, equitable, favourable and transparent conditions for Investors of other Contracting Parties to make Investments in its Area.' Article 10(2) of the ЕСт, however, only requires states to 'endeavour' to accord MFN and National Treatment to investors. Often, such pre-establishment rights are also subject to exceptions, particularly when it comes to 'subsidies' or 'procurement' decisions; see e.g. Mesa Power Group v Canada, PCA Case No. 2012-17, Award, 24 March 2016, paras 378-507. 
Some investment treaties go even further in limiting the discretion of host states to impose so-called performance requirements on investors. Performance requirements involve the imposition of conditions on companies relating to various aspects of their operations and they are often used by host states to 'help materialize expected spill-over effects from foreign investment.'71 Investments treaties do not prohibit all forms of performance requirements, rather they tend to target those that create significant economic inequalities, such as conditions requiring the purchase of local goods or services, conditions relating to the achievement of certain levels of exports or foreign exchange earnings, or conditions mandating the transfer of technology. ${ }^{72}$ Investment treaties usually address performance requirements relating to both the authorization or continuing operation of an investment, as well as similar conditions attached to advantages, such as loans, grants or subsidies.

The interpretation of the performance requirements provision in the NAFTA was raised in the case of Mobil and Murphy Oil $v$ Canada, in which the two oil companies challenged the revision of certain requirements concerning expenditure on research and training activities. Both companies had accepted certain expenditure requirements at the time when they made the investment. However, the Canadian authorities introduced revised guidelines in 2004, which the investors claimed significantly increased the burden imposed upon them to carry out these sorts of activities. In particular, the new guidelines required that expenditure should meet a certain level during specified periods. The companies argued that the revisions constituted a breach of, inter alia, the NAFTA provisions on performance requirements. The principal issue in dispute was whether the changes could be considered as falling within the prohibition on performance requirements 'to purchase, use or accord a preference to ... services provided in its territory' under Article 1106(1)(c) of the NAFTA. Research and training were both held to be services for the purposes of the NAFTA. ${ }^{73}$ Yet, Canada argued that the 2004 guidelines did not expressly compel the investors to use particular local services in order to meet their commitments. In rejecting the Canadian defence, the Tribunal looked beyond the actual text of the guidelines to determine their de facto effect, concluding that '[they] are designed to ensure that expenditures for [research and training] services occur in the Province, and thereby implying a legal requirement for

71 See 2015 Investment Policy Framework for Sustainable Development, 'Policy Options for International Investment Agreements,' example of Standards of treatment and protection. Available at: <http://investmentpolicyhub.unctad.org/ipfsd/section/3/toc-item -details/277>.

72 See e.g. TPP, Article 9.10; NAFTA, Article 1106.

73 Mobil (n45) para. 221. 
the purposes of Article 1106. ${ }^{14}$ The majority of the tribunal also took a restrictive interpretation of the reservations to this obligation. ${ }^{75}$ This case serves as a reminder of the important constraints that may be imposed by investment agreements.

\subsubsection{Post-investment Protection}

Once an investment has been made, one of the greatest risks that can face an investor is having their property or assets taken by the host state without justification. To counter such threats, most investment agreements contain provisions prohibiting a state from nationalizing or expropriating an investment without due process and without payment of compensation. ${ }^{76}$ Many agreements also prohibit a host state from restricting or delaying the transfer of profits or proceeds of an investment. ${ }^{77}$ Claims based upon such provisions are rare, as states do not often have recourse to such heavy-handed tactics. In contrast, it is much more common for international investment law to be used to challenge more subtle changes to the legal framework applicable to investors.

One of the most difficult issues in investment arbitration is the extent to which investment protection standards restrict the ability of host states to increase taxes or strengthen regulations after an investment has been made.

Early case law suggested that standards of protection could operate in such a way to significantly constrain states in their exercise of regulatory powers and there was a fear that investment law may have a 'chilling effect' on regulation. ${ }^{78}$ This is particularly the case when tribunals emphasized the need for stability when interpreting investment protection standards in light of the legitimate expectations of investors. ${ }^{79}$

74 Ibid, para. 242. See also para. 238.

75 This decision was subject to a dissenting opinion by Professor Philippe Sands QC.

76 E.g. ECT, Article 13; NAFTA, Article 1110.

77 E.g. ЕCT, Article 14.

78 See e.g. J. Bonnitcha, 'Outline of Normative Framework for Evaluating Interpretation of Investment Treaty Protections, in C. Brown and K. Miles (eds), Evolution in Investment Treaty Law and Arbitration (CUP, 2011) 133-140; see also K. Tienhaara, 'Regulatory Chill and the Threat of Arbitration', in C. Brown and K. Miles (eds), Evolution in Investment Treaty Law and Arbitration (CUP, 2011) 606-627.

79 Legitimate expectations has featured in the interpretation of both the indirect expropriation standard (Tecmed v Mexico, ICSID Case No. ARB (AF)/00/2, Award, 29 May 2003, para. 122) and the fair and equitable treatment standard (Biwater Gauff $v$ Tanzania, ICSID Case No. ARB/05/22, Award, 24 July 2008, para. 602). See discussion in Y. Levashova, 'Fair and Equitable Treatment and the Protection of the Environment: Recent Trends in Investment Treaties and Investment Cases', in Y. Levashova, T. Lambooy and I. Dekker (eds), Bridging the Gap between International Investment Law and the Environment (Eleven International Publishing, 2016) 64. 
Yet, more recent developments in investment case law would seem to suggest that the standards should not be interpreted in a restrictive manner and states possess a degree of flexibility when deciding how to regulate investments, particularly when 'defining the issues that affect its public policy or the interests of society as a whole, as well as the actions that will be implemented to protect such values. ${ }^{\prime 80}$ On the basis of this case law, it is clear that international investment law cannot be relied upon to shield investors from any changes to the legal framework. This was made explicit in Mobil and Murphy Oil v Canada when the Tribunal held that the fair and equitable treatment standard 'was never intended to amount to a guarantee against regulatory change, or to reflect a requirement that an investor is entitled to expect no material changes to the regulatory framework within which an investment is made. ${ }^{81}$ In another recent case involving the modification of the regulatory framework for the renewable energy sector, the Tribunal similarly held that 'in the absence of a specific commitment toward stability, an investor cannot have a legitimate expectation that a regulatory framework ... is not to be modified at any time to adapt to the needs of the market and to the public interest.' ${ }^{\prime} 2$ Moreover, it is also now generally accepted that 'non-discriminatory regulatory actions by a Party that are designed and applied to protect legitimate public welfare objectives, such as public health, safety and the environment, do not constitute indirect expropriations, except in rare circumstances. ${ }^{83}$

Similar considerations apply to the taxation framework that is applied to investors. For example, in Paushokv Mongolia, the Tribunal held that 'significant modification of taxation levels represents a serious risk, especially when investing in a country at an early stage of economic and institutional development' and the imposition of a windfall tax imposed by Mongolia could not by itself constitute a breach of the fair and equitable treatment standard. ${ }^{84}$ The Tribunal went on to note that an investor could seek to protect itself by negotiating a stability agreement with the government, but '[i]n the absence of such a stability agreement, Claimants have not succeeded in establishing that they had legitimate expectations that they would not be exposed to significant

8o $\quad$ Tecmed (n79) para. 122.

81 Ibid, para. 153. See also Saluka Investments $v$ Czech Republic, UnCITRAL Arbitration, Partial Award, 17 March 2006, para. 306; Perenco v Ecuador, Icsid Case No. ARB/08/6, Decision on Remaining Issues of Jurisdiction and Liability, 12 September 2014, para. 560 .

82 Charanne Construction Investments $v$ Spain, Stockholm Chamber of Commerce Arbitration No. 062/2012, Award, 21 January 2016, para. 510 (unofficial translation by Mena Chambers). The majority of the Tribunal also rejected the proposition that the regulatory framework in that case involved an implicit stabilization clause. See however the dissenting opinion of Prof. Guido Santiago Tawil.

83 TPP, Annex 9B, para. 3(b).

84 Paushokv Mongolia, UnCITRAL Arbitration, Award, 28 April 2011, para. 302. 
tax increases in the future. ${ }^{85}$ Even a $99 \%$ windfall tax applied to oil industry profits was held not to violate the expropriation standard in Perencov Ecuador because the tax did not affect the operation and management of the company, nor did it come close to extinguishing the business. ${ }^{86}$

\subsection{Balancing Investment Protection and Environmental Concerns in the Context of Seabed Investments \\ 4.2.1 Need for Flexibility in Interpreting Investment Standards}

The preceding analysis suggests that the requirements of investment protection must be balanced against the interests of the host state to protect certain public interests. The protection of the environment clearly counts as an interest that can be promoted by the host state in exercising its regulatory powers. Indeed, it must be appreciated that international law places obligations on the coastal state to 'adopt laws and regulations to prevent, reduce and control pollution of the marine environment arising from or in connection with seabed activities subject to their jurisdiction and from artificial islands, installations and structures under their jurisdiction.' ${ }^{87}$ The precise content of these laws and regulations will be determined in the first instance by the coastal state, albeit subject to an overarching obligation to exercise due diligence to minimize the risk of significant harm to the marine environment. ${ }^{88}$ It has also been argued that, in light of the uncertainties concerning the impact of new technologies on the marine environment, emerging seabed industries require a precautionary approach to regulation, ${ }^{89}$ meaning that states should adopt measures to prevent serious and irreversible harm, even if there is not yet proof that harm may occur. ${ }^{90}$ Meeting the due diligence obligation imposed by international law may also require the rules and standards to be adapted over time as perceptions of risks change in response to developments in our understanding of the oceans. ${ }^{91}$

85 Ibid., para. 302 .

86 Perenco $(\mathrm{n} 81)$ paras $680-687$.

87 UNCLOS, Article 208(1). This provision must also be read in light of Article 194(3)(c).

88 On the due diligence standard, see South China Sea Arbitration, PCA Case No 2013-19, Merits Award, 12 July 2016, para. 944. See also J. Harrison, Saving the Oceans through Law: The International Legal Framework for the Protection of the Marine Environment (oup, 2017) 209-225.

89 See e.g. The World Bank, Precautionary Management of Deep Sea Mining Potential in Pacific Island Countries (2016).

9o See 1992 Rio Declaration on the Environment and Development, Principle 15.

91 See Advisory Opinion on Responsibilities and Obligations of Sponsoring States with Respect to Activities in the Area (2011) ITLos Reports 10, para. 117. On the importance of adaptive 
There is little doubt that these international obligations relating to the protection of the marine environment provide relevant context for informing the scope and content of international investment law. As noted by in one recent investment award, 'consideration of a host state's international obligations may well be relevant in the application of [an investment treaty standard] to particular circumstances. ${ }^{92}$ Yet, it is not to say that these environmental obligations will automatically take priority. Rather, one should pursue 'mutual supportiveness' 93 of economic and environmental objectives and, if possible, it is for the Tribunal to identify an interpretation that reconciles both sets of rules.

The need for flexibility in the interpretation of investment rules has been expressly recognised in relation to industries where there are known environmental concerns. ${ }^{94}$ This is an area in which states possess a high level of deference ... [and] it is not for an investor-state tribunal to second-guess the substantive correctness of the reasons which an administration were to put forward in its decisions, or to question the importance assigned by the administration to certain policy objectives over others. ${ }^{95}$ However, there are certain principles that host states must nevertheless respect when developing environmental regulations, as discussed in the following section.

\subsubsection{Guiding Principles When Developing National Environmental}

Regulations in Order to Satisfy International Investment Law

Firstly, tribunals have stressed the need for states to take a cooperative approach when introducing changes to the legal framework, ${ }^{96}$ particularly where procedures for consultation or negotiation are themselves recognized in the applicable laws. ${ }^{97}$ At a minimum, states should avoid conduct that demonstrates 'a lack of due process leading to an outcome which offends judicial propriety - as might be the case with a manifest failure of natural justice in

management as a regulatory approach to environmental protection, see Addis Ababa Principles and Guidelines for the Sustainable Use of Biodiversity, Practical Principle 4.

92 Peter Allard v Barbados, UnCitral Arbitration, Award, 27 June 2016, para. 244. In this case, the Tribunal was talking about the full protection and security standard.

93 See e.g. R. Pavoni, 'Mutual Supportiveness as a Principle of Interpretation and Law-Making' (2010) 21 E.J.I.L. 649-679.

94 Methanex v United States of America, UnCitral Arbitration, Final Award, 8 March 2005, Part IV, Chapter D, para. 9.

95 Crystallex International Corporation v Venezuela, ICsid Case No. ARB(AF)/11/2, Award, 4 April 2016, para. 583. See also Mesa Power (n70) para. 505.

96 Suez and others $v$ Argentina, ICSID Case No. ARB/03/19, Decision on Liability, 30 July 2010, para. 223. 
judicial proceedings or a complete lack of transparency and candour in an administrative process. ${ }^{98}$ The threshold for a breach of relevant investment standards is, however, a high one, which requires something more than a 'perceived unfairness.' 99

Secondly, international investment law would prevent states from reneging on clear and explicit representations that were made by the state in order to induce the investment and relied upon by the investor. ${ }^{100}$ Even in this scenario, the investor may not be successful in their claim unless they can show that they have relied upon the representation to their detriment and the breach of the representation was in some way arbitrary or unreasonable. ${ }^{101}$

Thirdly, states must take the least restrictive option that is available to them to achieve their environmental objectives. In other words, 'where a state can achieve its chosen level of environmental protection through a variety of equally effective and reasonable means, it is obliged to adopt the alternative that is most consistent with open trade.'102 This is an important consideration in the field of marine environmental protection, where the due diligence obligations under UNCLOS would appear to leave a degree of discretion to states as to how they comply.

Fourthly, there may be a potential breach of relevant investment standards if the state can offer no reasonable explanation for a proposed change in the regulatory framework. In other words, there must be some evidential basis for a measure, if it is not to be considered as 'arbitrary'103 or 'disproportionate.'104 Thus, the denial of a permit was found to be a violation of international investment law in Crystallex $v$ Venezuela because it was based upon reasons that had not been raised in the exchanges between the company and the state, whilst ignoring the scientific evidence that had been submitted as part of the application. ${ }^{105}$

That is not to say that there must always be clear proof of environmental harm before a host state may take action. Article 201 of UNCLOS encourages

98 Waste Management v Mexico, ICSID Case No. ARB(AF)/00/3, Award, 30 April 2004, para. 98. See also Glamis Gold $v$ United States of America, Uncitral Arbitration, Award of 8 June 2009, para. 627; Mobil (n45) para. 152.

99 Perenco (n81) para. 559. See also Bilcon v Canada, uncitral Arbitration, Award, 17 March 2015, para. 444.

100 Mobil (n45) para 156. See also Glamis Gold (n98) para. 621; Suez (n96) para. 226.

101 See e.g. Mesa Power (n7o) para. 502. See also Allard (n92) paras 200-204.

$102 S$ S Myers v Canada, UNCITRAL Arbitration, Partial Award, 13 November 2000, para. 221.

103 Waste Management (n94) para. 98. See also Glamis Gold (n94) para. 627; Mobil (n43) para. 152.

104 See Tecmed (n75) para. 122.

105 Crystallex (n95) paras 591-597. 
'appropriate scientific criteria for the formulation and elaboration of rules, standards and recommended practices and procedures for the prevention, reduction and control of pollution of the marine environment,' 106 but it does not specify how much scientific evidence is necessary and it has been suggested that 'the [precautionary approach] will have a role to play in the operation of Article 201 as the establishment of appropriate scientific criteria will need to acknowledge potential risks even if they are not fully known.107 The precautionary approach is also accepted as being implicit in the obligation of due diligence. ${ }^{108}$ It follows that the precautionary approach may be invoked to justify action for the protection of the environment, even when there is no conclusive proof that environmental harm will occur. ${ }^{109}$ At the same time, there are limits inherent in the precautionary approach itself, which is apparent from recent case law on the subject.

Windstream Energy $v$ Canada is one of the few investment cases in which the precautionary approach has been raised in proceedings. The case involved an American investor challenging a moratorium on offshore wind farms in Lake Ontario in Canada. The company claimed that it had invested in a project for offshore wind development based upon encouragement from the Government of Ontario, which later changed its mind and decided to halt any further development until further scientific studies had been carried out. Canada justified its decision to take 'a cautious approach and develop a comprehensive regulatory framework before allowing any offshore wind energy facilities to be built' as a reasonable use of its regulatory powers. ${ }^{110}$ This position was supported by the Tribunal, which accepted that Ontario's policy was 'at least in part driven by a genuine policy concern that there was not sufficient scientific support for establishing an appropriate ... exclusion zone for offshore wind projects.'111 The reference to a 'genuine' policy concern is important because it emphasizes that there is a minimum threshold of evidence that must be met in order to invoke

\footnotetext{
106 UNCLOS, Article 201.

107 T Stephens, 'Article 201', in A Proelß (ed.), United Nations Convention on the Law of the Sea: A Commentary (Beck 2017) 1345 .

108 Sponsoring States Advisory Opinion (n91) para. 131.

109 On the relationship between the precautionary approach and the standard of proof and sources of evidence, see J. Harrison, 'Addressing the Procedural Challenges of Environmental Litigation in the context of Investor-State Arbitration, in Y. Levashova et al (eds), Bridging the Gap between International Investment Law and the Environment (Eleven International Publishing, 2016) 99-104.

110 See e.g. Windstream Energy $v$ Canada, Government of Canada's amended Response to the Notice of Arbitration, 5 December 2013.

111 Windstream Energy $v$ Canada, UnCitral Arbitration, Award, 27 September 2016, para. 376 .
} 
the precautionary approach. Thus, as explained by another international tribunal, even a precautionary approach requires that 'there are plausible indications of potential risks.'112 Such an understanding ensures that environmentalism is not used as a pretext for measures that substantially interfere with investment activity.

Indeed, another restriction is that the precautionary approach only justifies 'cost-effective' measures. ${ }^{113}$ In other words, a tribunal could still evaluate the effects of a measure on an investor, even if it accepts that some sort of precautionary measure would be appropriate. In some cases, complete restriction may be justified, but this outcome should not be assumed without some sort of assessment of alternative measures. Furthermore, the Tribunal in Windstream Energy explained that, even if a moratorium would be appropriate, the precautionary approach does not give a state freedom to postpone a project for as long as it wants - the Tribunal ultimately held that Canada had violated the fair and equitable treatment standard because it had done 'relatively little to address the scientific uncertainty surrounding offshore wind that it had relied upon as the main publicly cited reason for the moratorium.'114 This would seem to suggest that the precautionary approach may justify provisional restrictions on an investment, but a state should take further steps to gather the scientific evidence that may be necessary to make a full assessment of the environmental effects of an activity. This interpretation of the precautionary approach follows the rules agreed in other economic treaty regimes, where states are permitted to provisionally adopt restrictive measures where there is scientific uncertainty, but states must 'seek to obtain the additional information necessary for a more objective assessment of risk and review the [provisional] measures accordingly within a reasonable period of time.'115

Ultimately, it is important to acknowledge that there may be situations in which investment rules will require protection to be afforded to an investor, despite the environmental concerns of a state. This may be particularly true in the case of regulatory measures which '[render] the value to be derived from their activities so marginal or unprofitable as to effectively deprive them of

\footnotetext{
112 Sponsoring States Advisory Opinion (n91) para. 131.

113 See 1992 Rio Declaration on Environment and Development: 'Where there are threats of serious or irreversible damage, lack of full scientific certainty shall not be used as a reason for postponing cost-effective measures to prevent environmental degradation.' The requirement of cost-effectiveness was emphasized in Sponsoring States Advisory Opinion (n91) para. 128.

114 Windstream Energy (n111) para. 378.

115 WTO Agreement on the Application of Sanitary and Phytosanitary Measures, Article 5(7).
} 
their character as an investment.'116 This is a very high threshold, but it might be met, for example, in the case of a declaration of a marine protected area (MPA), in which all activity is prohibited. Such findings have been made in cases concerning the establishment of terrestrial protected areas, for example in Metalclad $v$ Mexico, where the Tribunal held that an Ecological Decree designating a cacti reserve in the area of the investment constituted an act tantamount to expropriation because it severely restricted the carrying out of any activity within the area. ${ }^{117}$ The fact that the international community has repeatedly endorsed the development of MPA networks would not prevent such a finding. ${ }^{118}$ After all, states have a large amount of discretion as to which areas they designate as MPAs, as well as what activities they restrict therein. Moreover, it must be understood that international investment law would not prevent the establishment of a MPA, but the state would be required to pay compensation to investors that are prevented from continuing activities that they had been previously authorized to conduct in that area. In this respect, it has been noted that ' $[\mathrm{w}]$ hile an expropriation or taking for environmental reasons may be classified as a taking for a public purpose, and thus may be legitimate, the fact that the [p]roperty was taken for this reason does not affect either the nature or the measure of the compensation to be paid for the taking.'119 This is a reminder that coastal states will have to take into account international investment law when carrying out their regulatory mandate in relation to seabed activities and the establishment of MPAs. It also suggests that, in order to avoid conflicts, coastal states should, as far as possible, try to identify ecosystems that require protection prior to authorizing investments in the relevant areas. ${ }^{120}$

\section{5}

\section{Conclusion}

It is likely that uses of the seabed will continue to increase in the coming years, both in terms of an expansion of existing activities and the emergence of new ones. In the exercise of their sovereignty and sovereign rights over the seabed,

\footnotetext{
116 EnCana Corporation v Ecuador, LCiA Case No. UN 3481, Award, 3 February 2006, para. 174.

117 See Metalclad v Mexico, ICSID Case No. ARB(AF)/97/1, Award, 30 August 200o, paras 109-112.

118 See e.g. Sustainable Development Goal 14.5.

119 Santa Elena Development Company v Costa Rica, ICSID Case No. ARB/96/1, Award, 17 February 2000, para. 71.

120 To this effect, see UK House of Commons Energy and Climate Change Committee, The Future of Marine Renewables in the United Kingdom (2012) para. 92.
} 
coastal states have a broad degree of power to ensure that these activities are carried out in such a way that both provide benefits to local communities and do not cause serious or irreparable harm to the marine environment. This paper has explored the extent to which international investment law applies to the measures adopted by coastal states in relation to seabed activities and what constraints may be imposed on coastal states thereby.

It has been shown that there are clear arguments that investment treaties can be interpreted to apply to investments in all maritime zones of coastal states, even if they are not explicit in this respect.

The chapter also identified some situations in which the application of international investment law becomes more complex, notably seabed activities in joint development areas or disputed areas. Investors should be more cautious in these situations, as they may not necessarily benefit from the protections of international investment law. Thus, they may need to enter into special arrangements in order to receive the assurances that they may want before they invest. ${ }^{121}$ It is also important to remember that international investment law also does not extend to investments in areas beyond national jurisdiction.

When it comes to the substantive protection that may be enjoyed by an investor, it was argued that international investment law must be interpreted and applied in light of state's international commitments in relation to the protection of the marine environment, with a view to achieving mutual supportiveness between these two areas of law. The paper proposed a framework of principles to guide states in the exercise of their regulatory powers, in order to minimize any conflict with investment protection standards. In doing so, the paper identified the opportunities for applying a precautionary approach to seabed regulation, whilst also pointing out the limits of this principle as a defence to investment claims.

Ultimately, international investment law offers a large degree of discretion to states in exercising regulatory powers, although the precise limitations will depend upon the nature of the obligations they have undertaken in their investment treaties and the restrictiveness of measures that are adopted.

121 In this context, see the discussion in Tzeng $\left(\mathrm{n}_{53}\right)$ of contractual measures and political risk insurance. 